\title{
Resilience Planning and Urbanization Experience of Bayburt
}

\section{Defne DURSUN ${ }^{1 *}$, Doğan DURSUN ${ }^{1}$, Cansu GÜLLER ${ }^{1}$}

\begin{abstract}
Negative developments in the environment of the modern world such as pollution, disasters, scarcity of different sources and water resources, climate change and global effects of any local changes requires taking precautions and introduce the need for new approaches. The concept of "resilience" becomes a current issue in this process and it develops existing discussions on sustainability, management of risks and governance. Resilience is a capacity of system to cope with external unexpected risks. In the urban area, the concept means adaptation and coping capacity of urban systems against shocks and risks which may arise, disasters and emergencies. The main aim of this study is to evaluate existing urbanization practices of Bayburt in terms of the concept of resilience. In this context, consistency of existing urbanization dynamics and ecological system is questioned with resilience perspective. In the first stage, the resilience concept and its offers in the planning area are discussed. Then, framework for the analysis of Bayburt is presented. In the last part, economic, social and ecological risks are determined for the case study of Bayburt. In this stage, economic, social and ecological indicators (such as the change of employment, income and main economic activities; changing population, education and migration status, dependency ratios and welfare; changing land use characteristics in historical process) were used to define the existing situation of the city. Also, old plans of the city are analyzed. The findings show that urbanization policy and practices in Bayburt are the reasons of ecological risks. New planning approach should immediately be developed with the resilience perspective. Otherwise, the city will be faced with big risks in the near future in terms of livability.
\end{abstract}

Keywords: Resilient city, adaptation, planning, Bayburt

\footnotetext{
${ }^{1}$ Defne DURSUN (Orcid ID: 0000-0003-4560-744X), Doğan DURSUN (Orcid ID: 0000-0003-3791-0027), Cansu GÜLLER (Orcid ID: 0000-0001-5602-7948) Atatürk University, Faculty of Architecture and Design, Urban and Regional Planning Department, Erzurum, Turkey

*Corresponding Author: Defne DURSUN, defnedursun@gmail.com

The article was orally presented at the "International Conference on Spatial Planning and Sustainable Development" held at Chiba University (Japan) between 30 August-1 September 2019.
} 


\section{INTRODUCTION}

The concept of urban resilience is defined as the surviving capacity of urban systems, societies, individuals, organizations and enterprises after sudden shocks and threats. In fact, it can be called as a protection capacity which ensures the continuity of the systems with its basic functions and structure. In general, it is known that the concept has three basic aspects as persistence, adaptability and transformability (Frantzeskaki, 2016). The concept of resilience is related to the state of being prepared for future shocks and against the vulnerability (Eraydın, 2010; Adger, 2000). In other words, the concept of resilience, which can be defined as the predictive ability, is the mitigation of the impacts of crises and shocks through planning and system change by predicting them before (Aguirre, 2006). In other words, the concept includes not only the capacity to respond or adapt, but also the preventive arrangements against these shocks (Baud and Hordijk, 2009). In the past, it was the concept of ecological studies (Folke et al., 2000; Gunderson and Holling 2001) but now it is becoming a concept and approach that can be integrated into the urban planning, design and participation processes. The fact that urbanization has become a driving force of economic development with the concentration of capital on the production of urban built environment in the last years, the importance of the resilience has increased in sustainable development. In this development process, the concept, approach and policies of resilience in the city are directed towards multiple meanings, such as controlling changes, managing, struggling, adapting, creating opportunities in order to maintain the system (Eraydın, 2010). The concept provides a new framework of flexibility, viability and sustainability which enables risks turn into opportunities against urban threats (Frantzeskaki, 2016).

The first step of the planning approach for urban resilience is the determination of the fragilities and adaptation capacities of the cities. For this reason, identification of the indicators presenting the situation of cities, determination of the existing situation and definition of the principles and opportunities are important for the resilient urban planning approach.

In the guide, which is prepared for understanding the resilience of urban systems (Urban Resilience Research Prospectus, 2007), it is stated that quality of life, governance networks, community learning ability, social capital, production-demand-consumption chain, economic activities, institutional structure, built environment and the relations made with this environment should be understood. They have big importance in this understanding processes. This versatile structure of the concept of resilience has been studied in a number of studies (Eraydın, 2010; Adger, 2000; Berkes and Folke, 1998; Folke et al., 2000; Abel et al., 2006) and it is stated that ecological, social and economic resilience are related to each other (Dursun et al., 2020). Therefore, in order to increase the resilience capacity of an urban system and region, there is a need for analysis of ecological, social and economic indicators and improved plan solutions according to these analyzes.

The economic, social and ecological changes experienced in the world under the influence of globalization process reveal the fact that there may be new developments, threats, catastrophe or shocks. The concept of resilient city or resilience in urban planning provide an important framework for the sustainability of urban systems by including being prepared for such problems, controlling changes, adapting and creating opportunities.

\section{MATERIALS AND METHODS}

In this study, the urbanization dynamics of Bayburt city were evaluated from the perspective of ecological, economic and social resilience. At first, Bayburt's spatial development process was analyzed to evaluate ecological resilience. The spatial development process of the city dating back to the Seljuk period was examined historically and the urban development was discussed within the framework of 
ecological resilience by using previous urban development plans. The urban development areas proposed for the next twenty years in the city's last plan were evaluated in the context of their impact on the existing soil structure and ecological resilience.

Secondly, Bayburt's economic structure was analyzed to measure the economic resilience of the city. The economic data of Bayburt was evaluated on the basis of the years of the crisis in order to measure the capacity of the city to resist the economic shocks. In order to understand the overall situation in the city as well as the changes, comparisons were made with TRA1 Region and Turkey. In order to reveal the change in the distribution of population and capital, basic employment indicators and per capita national income and value-added distributions were examined and their changes were evaluated according to years. LQ analysis was performed to understand the current production situation and to reveal the leading sectors in Bayburt.

Finally, the social resilience of the city was evaluated by analyzing the changes in Bayburt's population structure and social indicators. Some variables of social resilience analyzed in this process related to quality of life and changes in human capital have also effects on economic resilience. The structure of the population, age distribution, dependency ratios, migration movements, education level are the analyzes used to provide information about the social resilience of the city.

\section{RESULTS AND DISCUSSION}

\section{Ecological Resilience}

The first discussions about the concept of resilience have been put forward in the field of ecology, and the economic and social dimensions have been discussed in the following period. The ecological resilience generally includes features that should be possessed for the continuity of ecosystems in a region. Cities or regions are adapting to changing conditions while increasingly damaging to the ecosystem in the world. The natural values lost during this process or the urban ecosystems that are established without taking these values into account decrease the resilience of regions by increasing the vulnerability of the region against disasters and changes. As well as the human driven developments, natural developments (such as disasters) damage the ecosystem. Damaged ecosystem will adversely affect today's living conditions and will create threats to the future. Urban sprawl and unplanned developments are the leading indicators of ecological resistance (Eraydin et al., 2011). These two developments reduce both ecological and spatial resistance. Therefore, the capacity of the city or region to adapt to changes is also decreasing. Unplanned development and urban sprawl process in the urban macroform decreases agricultural areas and adaptation capacities of the cities.

The effects of urban development models on ecosystem is a subject that is highly debated in the literature. The dispersed city and the compact city models have different effects on the environment during the urban growth process. However, it is a compact development that is less harmful in terms of ecological resistance. When we look at the development model of Bayburt city (Figure 1.a), it is seen that it is a city followed a compact development model until the 1950s and spread in all directions in the following years. Especially in recent years, the city macroform has a fringed pattern in all directions, including north-south and east-west corridors.

Bayburt is a settlement located at 1550 meters height, on the north-south direction of the Coruh River. Settlement is generally surrounded by mountainous and rocky areas as well as Bayburt plain on the west and Çoruh River on the east side. The city center is located on the north of the ErzurumGümüşhane highway and extend parallel to the Çoruh River. Historical process has shown that urban growth of Bayburt can be seen on two lines as Coruh and Erzurum-Gumushane highway. Settlement area has an irregular and scattered structure due to the development trend observed as unplanned and 
cadastral parcel based urban development after 1980s. In 1990s, industrial district and University campus were proposed to the west of the city and directed urban development towards the west side. Additionally, urban development towards the north and east is continuing, although the geographic features and natural thresholds limit city's development. It is clearly understood that the sprawled growth of the city through planned interventions will reduce the capacity to adapt to the future disasters and threat.

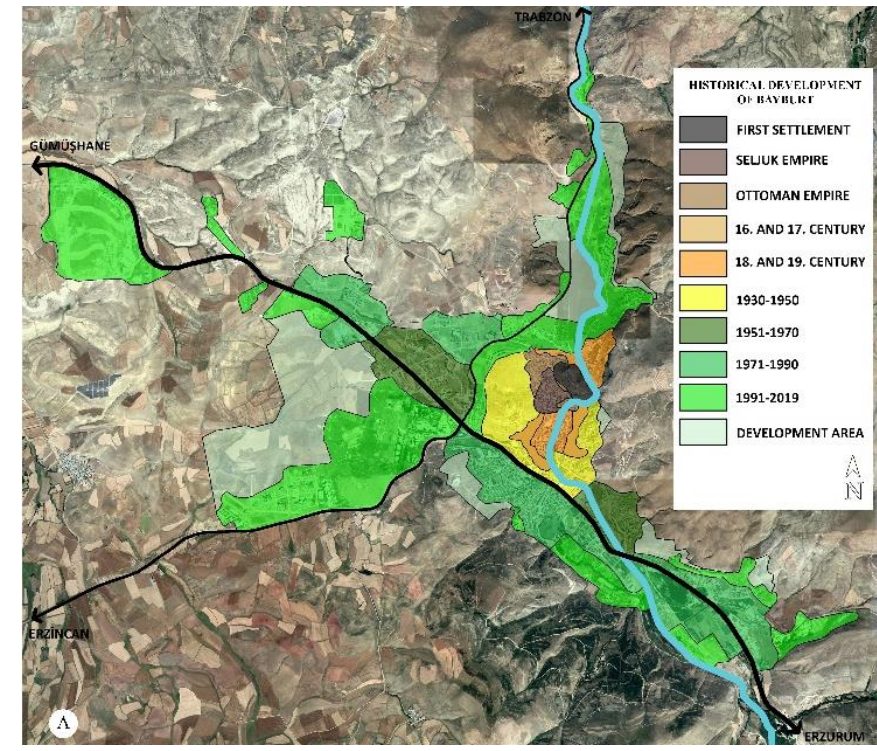

(A)

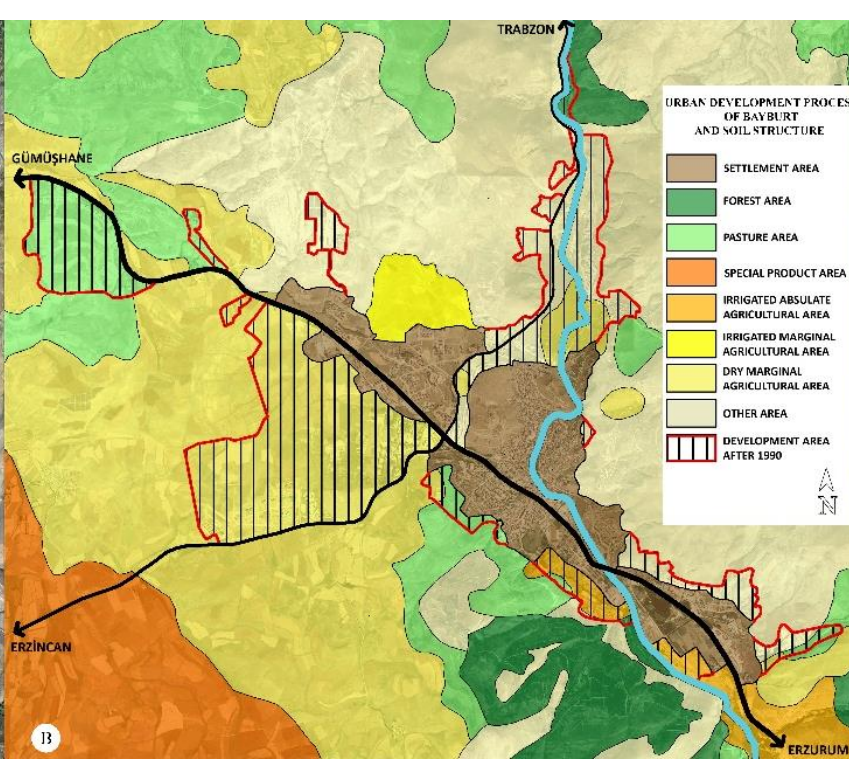

(B)

Figure 1. A) Historical development of the city; B) Urban Development Process of Bayburt and Soil Structure

When the urban development and macroform formation of the city is evaluated according to the soil structure after 1990 (Figure 1b), it is clear that a significant amount of agricultural land is opened up to urban development. It is seen that the proposed military area, university area and new residential development areas in the western part are on agricultural lands. Additionally, buildings were allowed on important agricultural lands in the north and south east part of the city. The opening of agricultural lands and grasslands to urban growth is negative development in terms of environmental and ecosystem sensitivity. Considering the development tendency of the city, it is understood that city will continue to develop over agricultural land in time and a situation will increasingly threaten ecological resistance in the future. The planned urban development pattern after 1990 and the suggested urban macroform had neglected ecologically sensitive areas and decreased adaptation capacity in the face of disasters and some other sudden developments.

When we examine the planned historical development of urban areas in Bayburt, we can understand that spatial and ecological risks are increasing day by day, agricultural areas and underground water resources are threatened and earthquake risk is neglected. The urban development has shown a growth that was realized in the form of sprawl and spreads after a planning period. This situation shows high ecological vulnerability and low resistance for Bayburt.

\section{Economic Resilience}

Developing the capacities of cities and regions provide them to be sensitive about and adapt changing conditions such as the changing flows, rivalry conditions, instantaneous crisis and alterations of global economy. The results given by cities to such crises and shocks varies (Eraydin et.al., 2011). 
While 'economically resilient cities' succeed to go back to their previous development levels and even go beyond it being more successful, some other cities/regions, that are not resilient, cannot succeed to compete with any crises and sometimes cannot go back from their existing development levels. However, third type of cities continue to pursue their existing development levels after such crisis and shocks. These cities/regions which are not effected by crisis are called 'resilient cities'. (Hill et. al., 2008).

The economic resilience of cities and regions is analysed through the investigation of the change in their economic performances after crises. Some of the major indicators used to measure the economic resilience are the change in capital and population, together with employment and quality of life. This perspective leads us to analyze the existing conditions of Bayburt through economic indicators such as its sectoral division, GDP change, financial and employment indicators, etc.

When we examine the Bayburt city from the economic resilience perspective, the economic crisis of Turkey in 2007, 2009, 2012 become important breaking points. They can help us to show economic changes of Bayburt in pre- and post-crisis period. However, there is a limitations of the data in our country. Even though the data about the years of the crisis could not be reached, the economic indicators and the current situation related to the most recent dates were examined and the economic resilience of the city was evaluated.

It is understood from the sectoral distribution (Figure 2) that there is a significant decrease in the agricultural sector and an increase in services and industrial sector. However, when we look at the total number of employment, we see a decrease. This situation is in parallel with the degradation of rural areas and the outward migration tendency remains a major problem in the region. Similar situation can be seen in Bayburt as the decline in the agricultural sector and increase in the industry and the services sector. Although the shares of industry and service sector increase, total number of the employment decreases in Bayburt.

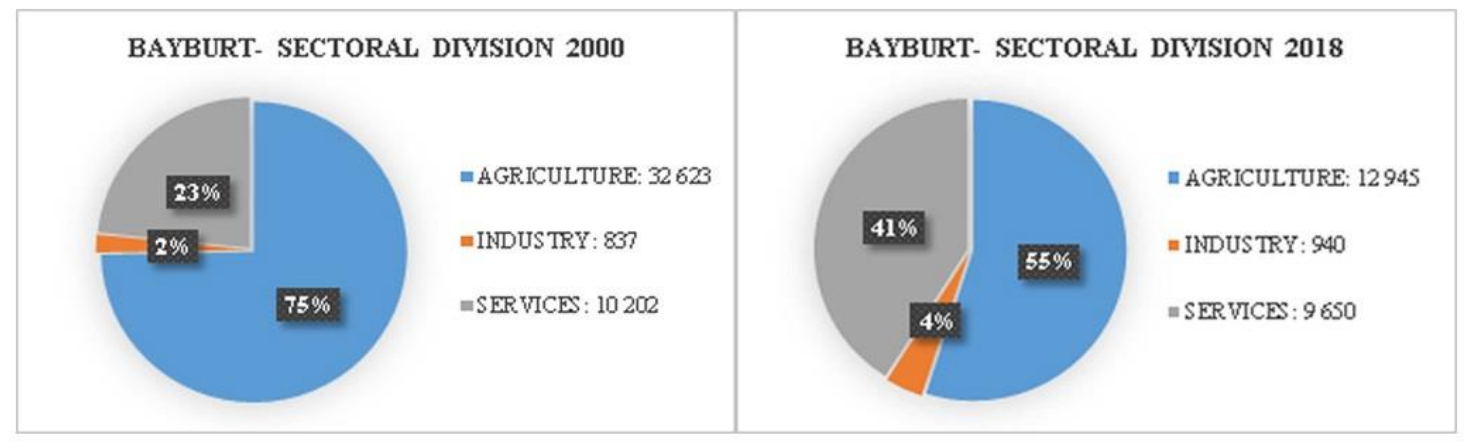

Figure 2. Sectoral Division (Source: TUIK, 2019a)

In terms of financial indicators, Table 1 shows that the share of savings deposits and the amount per capita in Turkey is increasing. Although this situation seems positive against the economic fragility, Bayburt's share in the country's economy is very low. Its resilience will decrease with the economic crises.

When the employment indicators of Bayburt were analyzed according to the crisis period in Turkey (Table 1), employment and labor force participation rate has decreased and the unemployment rate is seen to increase with it. Although the rate of active population increases every year in the city, the lack of a wide range of job opportunities brings about an increase in the unemployed population. The downward trend in employment and labor force participation rates may pose a threat to the Bayburt 
economy in the future. Bayburt cannot cope with the crisis and cannot return to its previous success in this process. This makes Bayburt economically non-resilient city.

Table 1. Annual percentage change in financial and employment indicators of Bayburt

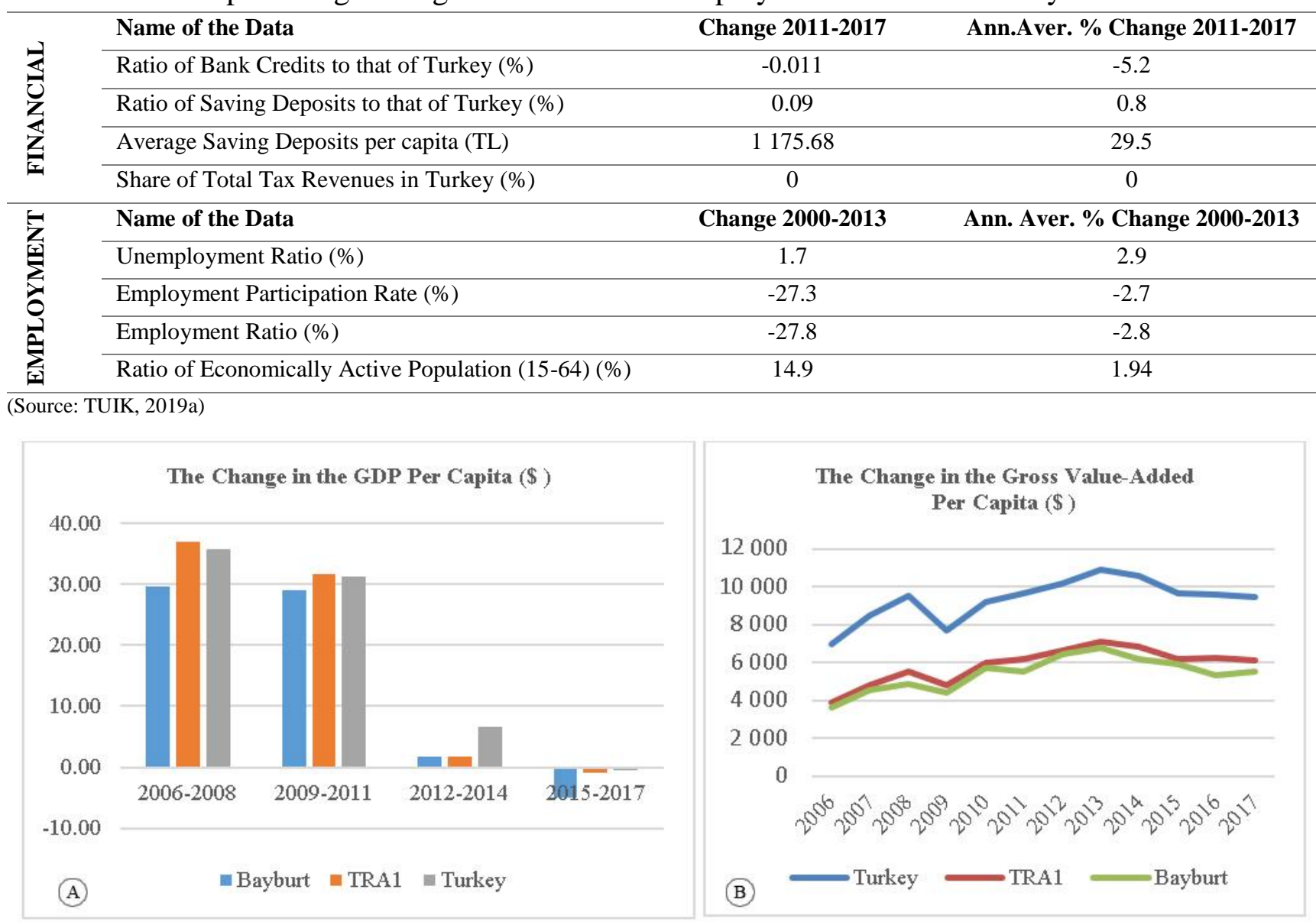

Figure 3. A)The Change in the GDP Per Capita; B)The Change in the General Income Status GVA Per Capita (Source: TUIK, 2019b)

Gross domestic product data (Figure 3a) is evaluated for 2007, 2009 and 2012 as the important turning points in Turkey. The per capita change of TRA1 until 2012 seems to be more positive. However, after 2012 this situation changed in the opposite direction. While the GDP per capita in the country and TRA1 region increased rapidly after 2012, Bayburt, lags behind although it has a low population. It suffers from economic shocks especially after 2012 and it has a much lower economic resilience. Nowadays, it is clear that Turkey, Bayburt and TRA1 region has experienced the loss of production and capital. This has decreased the economic resilience against future disasters and showed the fragile structure.

When the annual changes of the "gross value added per person" is analysed (Figure 3b), 2009, seems as an important breaking point for the city of Bayburt, TRA1 region and Turkey. The added-value obtained from production sector decreased significantly during the 2009 economic crisis. After this period, although the economy of country, TRA1 region and city recovered and per capita income level increased, there is still a decreasing and stable tendency in nowadays. The revenue per capita doubled for the TRA1 region and Bayburt after 2006; but they are still well below the average in Turkey.

For the analysis of spatial redistribution of population and capital for NUTS2 regions between 2000-2007 and 2007-2011 periods, the change of the shares of population and income per capita data of regions within Turkey are used. The regions at the bottom-left of the diagram are the ones that loose in 
this redistribution process. Figure 4 reveals that TRA1 Region is one of those losers. However, it also puts forward that TRA1 started to gain within the redistribution of population and capital after 2007 (especially in population- it still loses its population, but slower and lesser). According to the economic variables, the change in the relative position of TRA1 after 2007 is owed to the increase in construction sector. However, as the capital accumulated through construction sector did not transferred to investments producing more value-added goods; i.e to manufacture sector which has a strong multiplier effect on economic development. So, especially in a downsizing city like Bayburt, even this relatively positive development in the redistribution of population and capital is not enough to overcome the fragility of its economy.
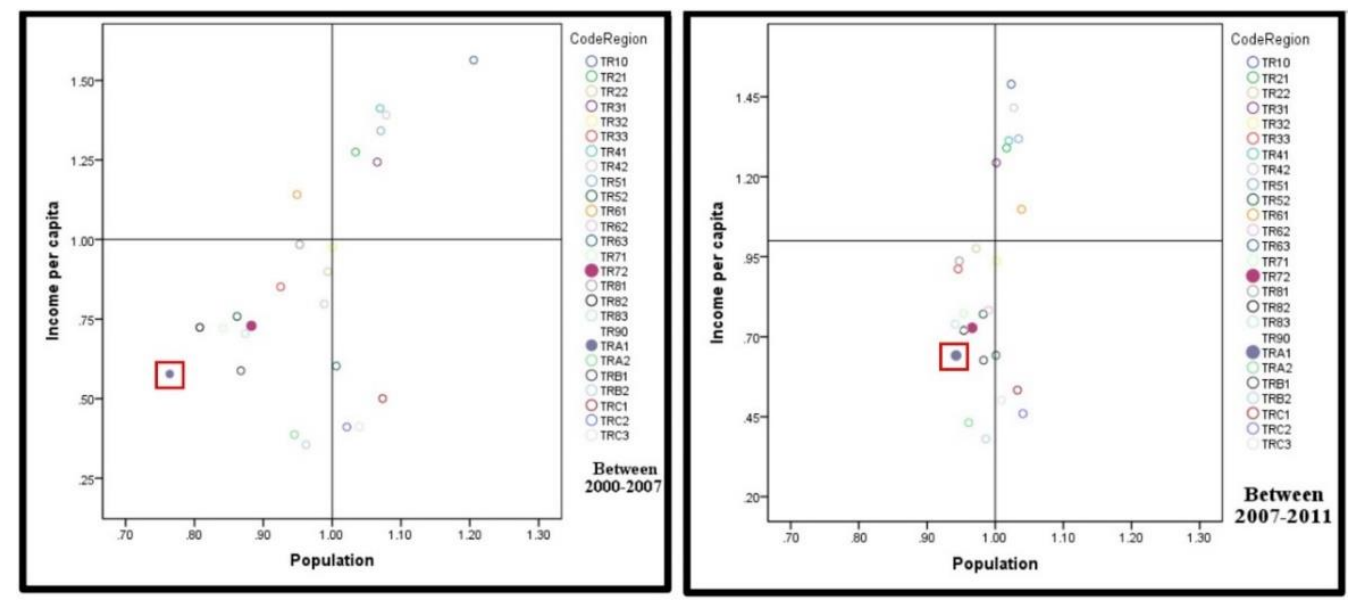

Figure 4. Re-distribution of Population and Capital in Space for NUTS2 Regions; between 2000 and 2011 (Source: Dursun, 2015)

Then, a location quotient (LQ) analysis is made for the local production facilities, in order to understand existing situation in industrial production capacity of Bayburt and the leading sub-sectors in the city. This analysis is important as it shows with which facility the city gains its production identity. Table 2 lists all the economic facilities in Bayburt of which LQ result is above 1 (15 of 99 activities according to NaceRev2 classification). According to this LQ analysis there is concentration for forestry, fisheries and non-metallic production sectors in Bayburt together with activities on service sectors. LQ analysis for Bayburt reveals that the economy of city is very fragile as the manufactural facilities which have multiplier effects on the economy are very limited in the city. It is important to increase investments and diversity in the production area. Otherwise, the tendency of the capital holders to migrate to the bigger cities (metropolitan ones) in the country may continue in the near future; which in turn increase the vulnerability of the local urban economy. Thus, it is important to increase the numbers and diversity of investments in the productive fields to provide economic resilience for Bayburt. Also, the varieties of service sector activities should be provided to increase the resilience of the city against future negative situations.

\section{Social Resilience}

The adaptation capacity of a city/region against new situations are determined by its social structure. Social resilience is defined as the capability of societies to overcome negative situations and also transfrom them to positive (Maguire and Hagan, 2007). The societies having three compenents of social resilience; i.e. resistance, recovery/overcoming and creativity; are assessed to have very high degree of resilience. 'Resistance' defines the survival capacities of societies from events such as scute shocks, disasters and their damaging results. Recovery/overcoming component of social resilience refers 
to the capability of any society to heal and turn back to the existing conditions before any crisis. The capacity of any society to learn from such unfavourable conditions and adapt to them to grow to an improved position is related to the 'creativity' of the society as a whole. These three components also affect and determines the economic resilience as they reveal an improvement not just in the social structure but also in the economy of the city/reigon.

The difficulty of measuring so many social variables quantitatively hardens the evaluation of social resilience. Thus, it is needed to analyse and discuss a list of different variables together. Demographic structure (together with the changes) of a settlement is the starting point of such an investigation; which includes education level, age and gender structure, age dependency ratios, population flows to and from the city. Additionally, variables that define the quality of life comes forward as the foremost indicators of social resilience; i.e. ratio of youngs in the population, labour force participation of women, levels of education of the ones who migrates to the city. Higher values of these indicators define higher levels of social resilience.

When the population change for Bayburt was examined in 1989 (Figure 5a), it is seen that the population and labor supply had shown a decreasing trend until 2010. However, after that time, serious fluctuations can be observed in the population (Figure 5b). The reason of this development is about the efforts of increasing municipal budget of Bayburt. People had changed their addresses to Bayburt although they are living in other cities. In this way, population of Bayburt seems high and budget coming from government will increase. In addition, people who want to use their votes in Bayburt during the 2015 general election had changed their addresses. It is difficult to determine the actual population of Bayburt due to the changing variables. Therefore, the fact that depending on the unknown population number and change ratios in the city, the labor supply potential cannot be calculated. Thus, the social fragility of the Bayburt increases and the continuity of this process will become a threat to the future.

Table 2. LQ Analysis (2017)

\begin{tabular}{|c|c|c|c|c|c|}
\hline \multirow[b]{2}{*}{$\begin{array}{l}\text { Branch of activities according to NACE Rev.2 } \\
\text { Classification }\end{array}$} & \multicolumn{2}{|c|}{ Bayburt } & \multicolumn{2}{|c|}{ Turkey } & \multirow[b]{2}{*}{ LQ } \\
\hline & $\begin{array}{c}\text { Number } \\
\text { of work } \\
\text { place }\end{array}$ & $\begin{array}{c}\text { N'of comp. } \\
\text { insured } \\
\text { person }\end{array}$ & $\begin{array}{l}\text { Number of } \\
\text { work place }\end{array}$ & $\begin{array}{l}\text { N'of comp. } \\
\text { insured person }\end{array}$ & \\
\hline Forestry and Logging & 8 & 703 & 3362 & 39705 & 28.38 \\
\hline Fisheries and Aquaculture & 2 & 6 & 1166 & 9062 & 1.06 \\
\hline Manufacture of non-metallic products & 22 & 280 & 14160 & 228354 & 1.97 \\
\hline $\begin{array}{l}\text { Electricity, gas, steam and air conditioning } \\
\text { supply }\end{array}$ & 12 & 76 & 15411 & 105934 & 1.15 \\
\hline Constructions of Facilities Excepting Buildings & 35 & 943 & 14684 & 417205 & 3.62 \\
\hline Accommodation & 23 & 130 & 18257 & 205291 & 1.02 \\
\hline Food and Beverage Services & 88 & 531 & 118311 & 658546 & 1.29 \\
\hline Veterinary Services & 4 & 23 & 2500 & 7594 & 4.85 \\
\hline Security and investigation activities & 21 & 276 & 21364 & 310499 & 1.42 \\
\hline Services to buildings and landscape activities & 76 & 1256 & 56188 & 733060 & 2.75 \\
\hline $\begin{array}{l}\text { Office administrative, office support and other } \\
\text { business support activities }\end{array}$ & 15 & 313 & 50579 & 419318 & 1.20 \\
\hline $\begin{array}{l}\text { Public administration and defence; compulsory } \\
\text { social security }\end{array}$ & 2 & 720 & 3439 & 130970 & 8.81 \\
\hline Education & 61 & 475 & 33985 & 536294 & 1.42 \\
\hline Social Services & 4 & 52 & 4954 & 51981 & 1.60 \\
\hline Sports, Leisure and Leisure Activities & 9 & 62 & 8098 & 46982 & 2.12 \\
\hline Total & 1236 & 9032 & 1874682 & 14477817 & \\
\hline
\end{tabular}




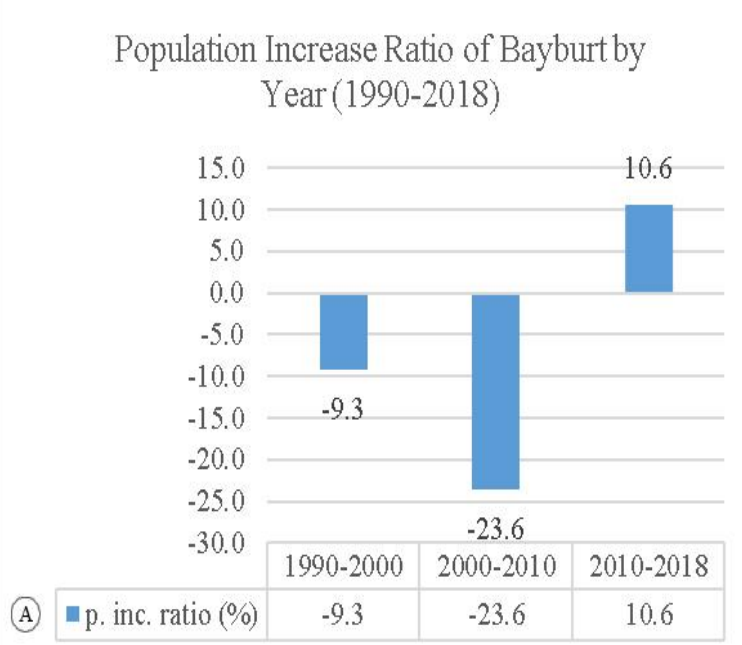

Population Increase Ratio of Bayburt by Year (2010-2018)

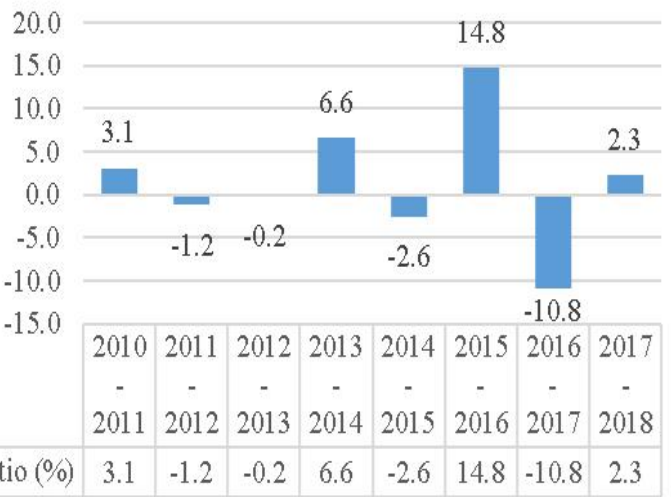

Figure 5. A) Population Increase Ratio of Bayburt by Year (1990-2018); B) Population Increase Ratio of Bayburt by Year (2010-2018) (Source: TUIK, 2019c, Regional Statistics-Population Census)

As much as the change of population is an important indicator for social resilience. Human capital and its change are important for the social resilience. The education level of a society is the determinant of supply for skilled labour; which is one of the most important variables to increase both social and economic resilience. Figure 6 indicates an increase in the education level (increase in the numbers of graduates from higher education and above). However, more than half of the population has primary school and lower education level. Bayburt as the city having low level of education in general is socially and economically fragile. As long as the development trend continues to increase the population with higher education degrees, the proportion of qualified population will increase and become more resistant to the future.

The age structure of a society demonstrates not only its social resilience but also the fragility points against contingencies. This indicator is important especially for the settlements trying to develop through intense industrial facilities; as it indicates the possible future labor supply; and thus possible fragilities. When the age distribution of the population of Bayburt is examined (Figure 7), it is seen that there is a conglomeration between the ages of 10 and 35 for 2008 and 2018. Between these years, the population has begun to grow older.

Population data show that Bayburt province is facing migration problem. When this situation, which can be evaluated as significant fragility of social structure, is examined in more detail (Figure 8), significant changes can be seen in the city after 2013. It is known that this population mobility does not express the real human mobility in Bayburt because the reason of the population change is about the aim of increasing municipal budget and the use of votes for general election. Predictions about the population change cannot be made for the future due to unknown actual migration rate. Therefore, measures against the threats cannot be taken. Such problems reduce social resilience by creating a significant vulnerabilities and weakening economic resilience due to the unpredictable future. 


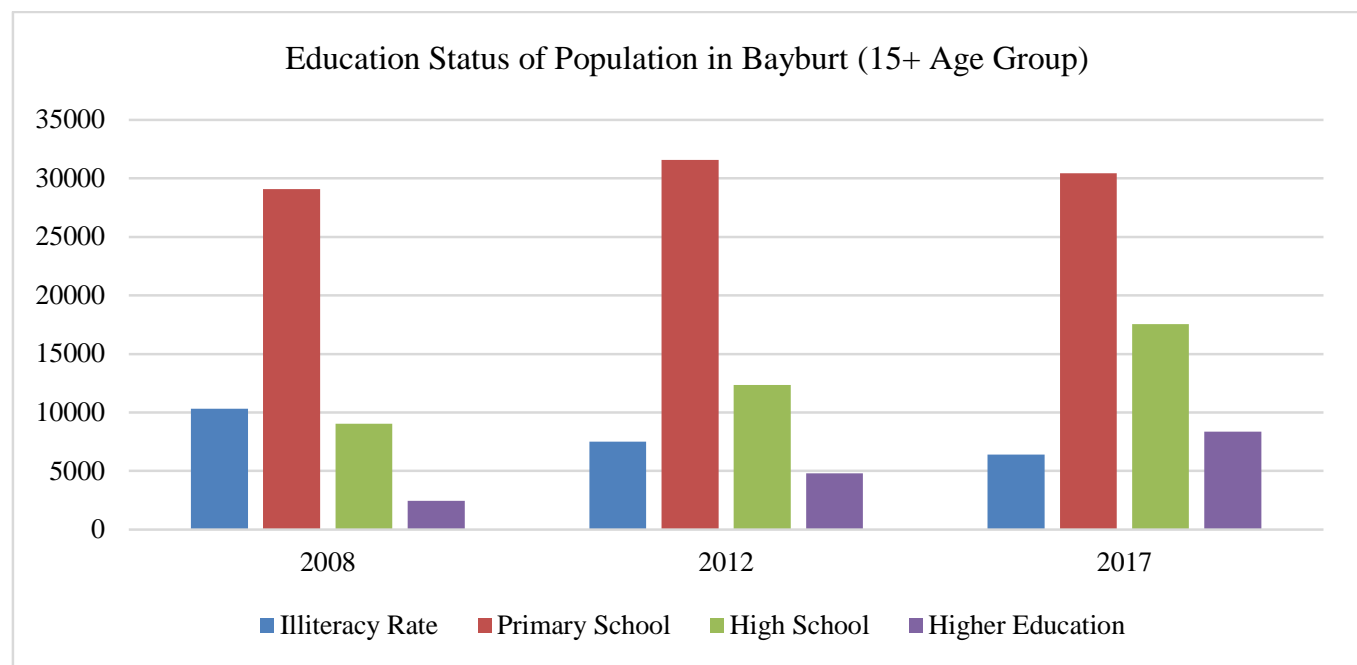

Figure 6. Education Status of Population (15+ Age Group), (Source: TUIK, 2019d, Regional Statistics; Education)

Age Pyramid of Bayburt(2008)

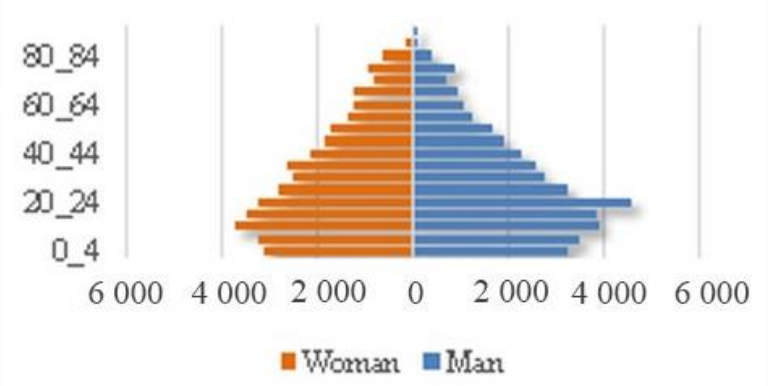

Age Pyramid of Bayburt(2018)

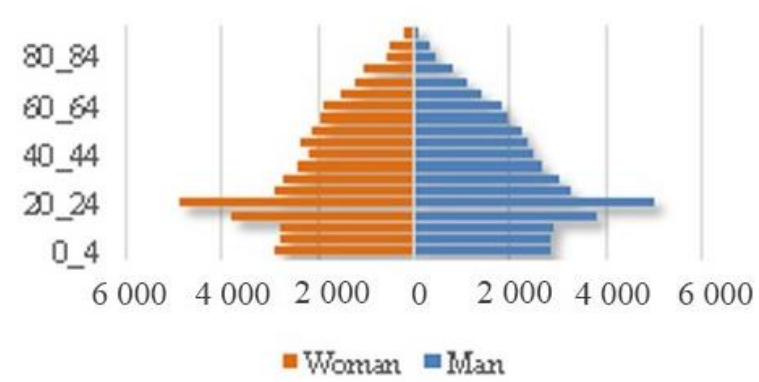

Figure 7. Age Pyramids of Bayburt (2008-2018) (Source: TUIK, 2019c)

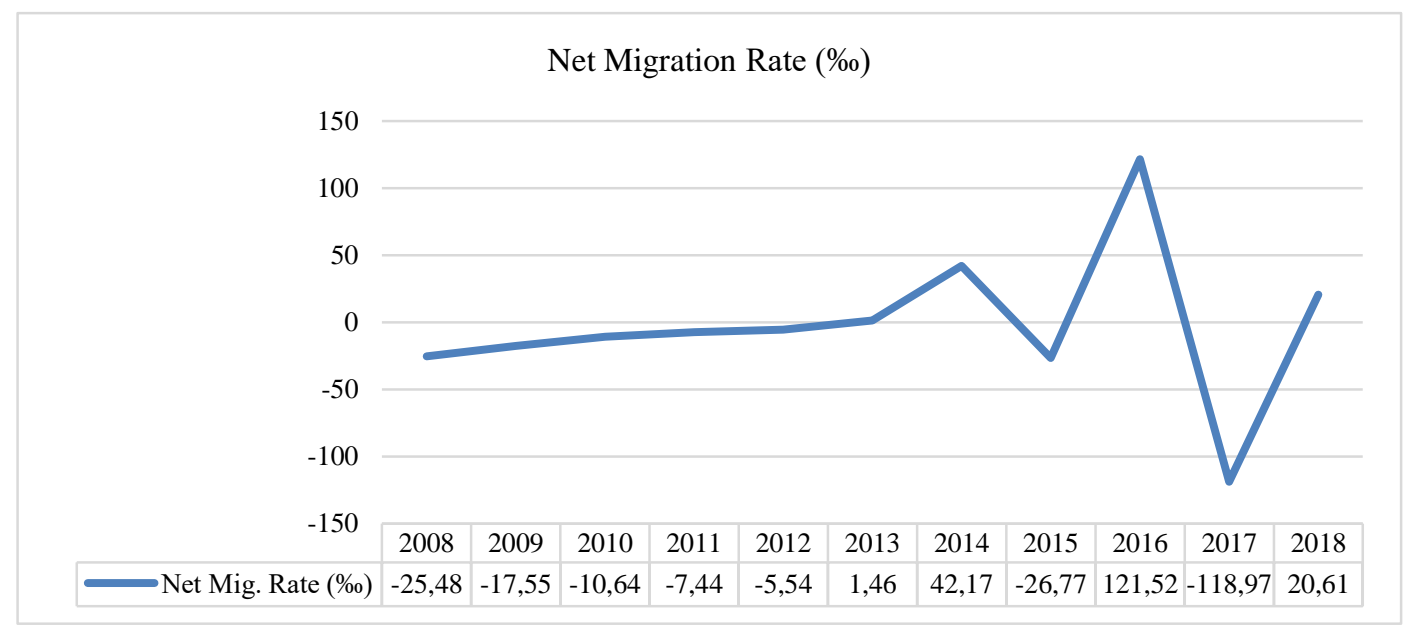

Figure 8. Net Migration Rate by Years (Source: TUIK, 2019e)

Age dependency ratio gives information about aging population of urban population. Figure 9 demonstrates a decrease in the dependency ratio of young people between 2008 and 2018; while the dependency ratio of elderlies has increased within the same period. Thus, the ratio of elderly people who do not attend the workforce in Bayburt is increasing as the society is aging; which by time increases the fragility of the city. 


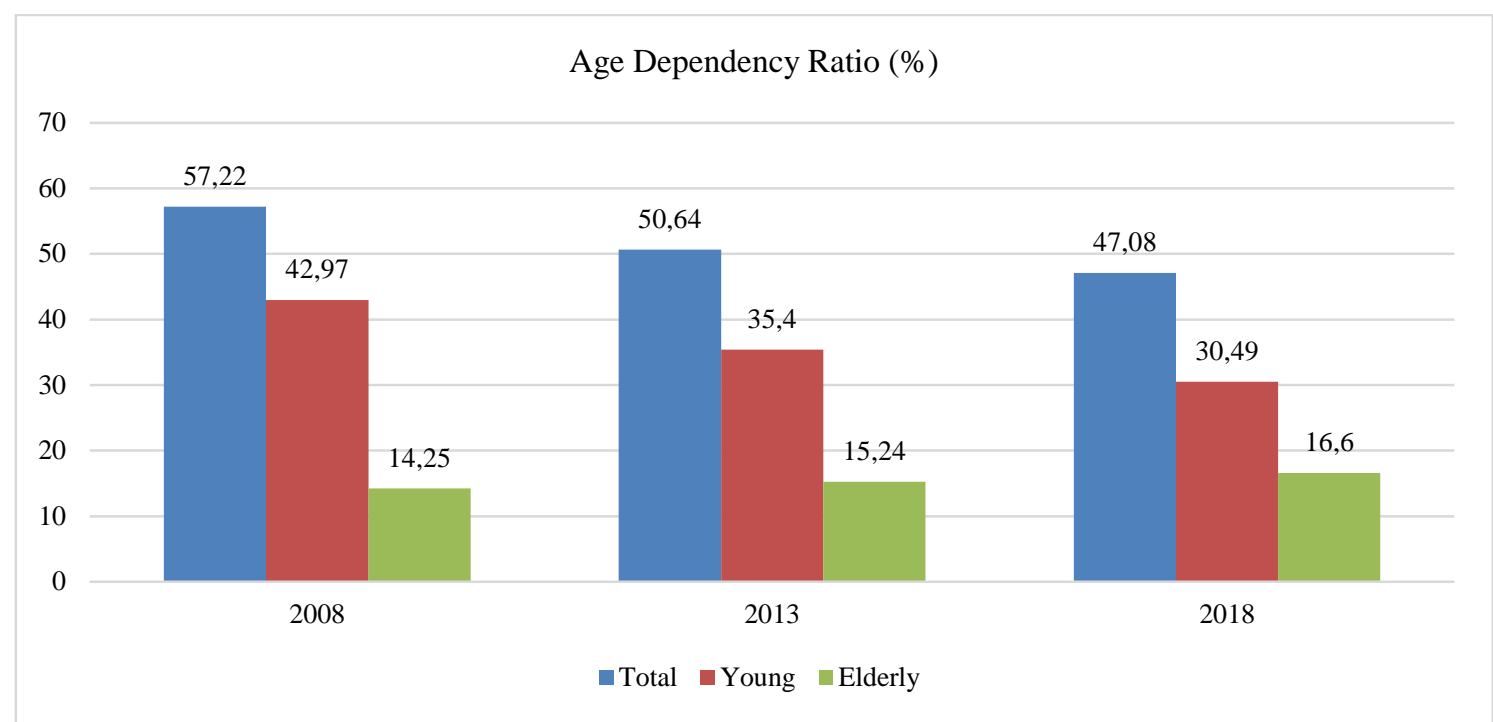

Figure 9. Age Dependency Ratio (Source: TUIK, 2019f)

Table 3 demonstrates clues regarding the change of the social structure in Bayburt. Together with the above variables, the change in the population density shows that Bayburt is a growing city especially with 2000s. The change in the rate of net migration shows, the migration from the city is continuing and increasing. Also, migration from Bayburt is increased with the last decade; which is a negative development regarding the social resilience of the city. Moreover, the urbanization ratio and average household size indicates that Bayburt has changed its social structure from rural to urban, especially after 2008. However, the variables in Table 3 shows that Bayburt is very fragile regarding its social structure; which demonstrates a weak social resilience within existing dynamics.

Table 3. The annual percentage change in population indicators and welfare indicators

\begin{tabular}{|c|c|c|c|c|c|}
\hline \multirow{11}{*}{ 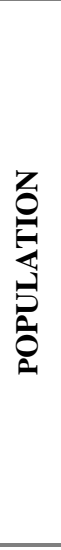 } & \multirow{3}{*}{$\begin{array}{c}\text { Name of the Data } \\
\text { Population Density }\left(\mathrm{km}^{2} \text { per capita }{ }^{-1}\right)\end{array}$} & \multicolumn{2}{|c|}{ Bayburt } & \multirow{3}{*}{$\begin{array}{c}\text { Change } \\
1.3\end{array}$} & \multirow{3}{*}{$\begin{array}{c}\begin{array}{c}\text { Ann.Aver. \% } \\
\text { Change }\end{array} \\
0.7\end{array}$} \\
\hline & & 2008 & 2017 & & \\
\hline & & 20.2 & 21.5 & & \\
\hline & \multirow{2}{*}{ Urbanization Ratio (\%) } & 2008 & 2017 & \multirow{2}{*}{12.9} & \multirow{2}{*}{2.9} \\
\hline & & 48.8 & 61.7 & & \\
\hline & \multirow{2}{*}{ Rate of net migration (\%) } & 2007-2008 & 2016-2017 & \multirow{2}{*}{-114.5} & \multirow{2}{*}{-63} \\
\hline & & -25.5 & -119 & & \\
\hline & \multirow{2}{*}{ Average Household Size } & 2008 & 2017 & \multirow{2}{*}{-1} & \multirow{2}{*}{-2.5} \\
\hline & & 4.4 & 3.4 & & \\
\hline & \multirow{2}{*}{ Dependency Ratio for 0-14 age (\%) } & 2008 & 2017 & \multirow{2}{*}{-13} & \multirow{2}{*}{-3.4} \\
\hline & & 43 & 30 & & \\
\hline \multirow{4}{*}{ 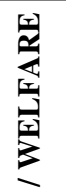 } & \multirow{2}{*}{$\begin{array}{l}\text { Ownership of automobile (\# } 10000 \\
\text { person }^{-1} \text { ) }\end{array}$} & 2008 & 2017 & \multirow{2}{*}{373} & \multirow{2}{*}{9.8} \\
\hline & & 424 & 797 & & \\
\hline & \multirow{2}{*}{$\begin{array}{l}\text { Housing Electric Consumption Per } \\
\text { Capita (KWh) }\end{array}$} & 2008 & 2017 & \multirow{2}{*}{483} & \multirow{2}{*}{6.9} \\
\hline & & 777 & 1260 & & \\
\hline 臣 & \multirow{2}{*}{ Housing Ownership (\%) } & 2000 & 2011 & \multirow{2}{*}{-5.6} & \multirow{2}{*}{-0.7} \\
\hline 至 & & 76.9 & 71.3 & & \\
\hline$>$ & \multirow{2}{*}{$\begin{array}{l}\text { Net Schooling Ratio at Secondary } \\
\text { Education }(\%)\end{array}$} & 2012 & 2017 & \multirow{2}{*}{-0.9} & \multirow{2}{*}{-0.2} \\
\hline$\Leftrightarrow$ & & 94.3 & 93.4 & & \\
\hline 承 & \multirow{2}{*}{$\begin{array}{l}\text { \# of Mobile Telephony Subscriptions } \\
\text { Per Capita }\end{array}$} & 2008 & 2017 & \multirow{2}{*}{0.1} & \multirow{2}{*}{1.6} \\
\hline$\sigma$ & & 0.7 & 0.8 & & \\
\hline
\end{tabular}

(Source: TUIK, 2019a, Province Indicators) 
Finally, it is needed to extend the analysis on social resilience to include the variables regarding the quality of life. Table 3 indicates such an evaluation for Bayburt and puts forward that the quality of life in Bayburt has seriously increased with 2000s. Even if this increases the social resilience and positively influence the future scenarios of the city, the analysis show that this is realized not because of any development regarding the city itself, but general political and economic policies of the country (Dursun, 2015). Thus, it is possible to remark this development as an evidence of the fragile structure of the city, as it shows how dependent the city to the developments in the country but does not generate any development by its own resources.

\section{CONCLUSION}

It is acknowledged that planning disciple should adopt resilience approach. Through a resilient planning perspective, planning should find new ways to increase the capacities of cities regarding possible shocks they may face. This study aims to use a resilience analysis for the investigation of Bayburt's urbanization experience, and questions the ecological, economic and social resilience of the city together with the capability of it to adapt.

Old urban plans and efforts to provide a planned development reveal that urbanization policies and practices of Bayburt creates fragilities. the city becomes vulnerable to the possible shocks, risks and threats because of the ecological risks created by such urbanization policies.

The economic analysis on Bayburt indicates the tendency to grow through service sector; which provides the capital accumulation. As it is stated in the Dursun's thesis (2015), the capital accumulated through service sector cannot be transferred to productive facilities, and thus the investors (capital holders) of the region tends to migrate to bigger cities just after they accumulate a significant capital; which is the explicit signal of economic development problems.

Social resilience analysis shows that the actual population living in the city cannot be estimated due the lack of detailed data and therefore it is difficult to predict the necessary urban needs and problems before urban shocks. At the same time, it is seen that the urban population has a tendency of aging; which increases dependency ratio of the elderly. The level education is relatively low in the city.

Therefore, the social structure of the city seems negative in terms of future scenarios. The qualified manpower is likely to migrate from the city; thus the manufactural industry of the city depends on unskilled labor. The possibility of Bayburt to be a resilient city; to endure a possible crisis and recover afterwards; reduces because of these characteristics.

Resilience analysis necessitates much more indicators having longer time periods in order to comprise more issues. However, the difficulty of finding each data for the same level of analysis (especially for cities) and their inconsistencies according to the change of Turkish statistical data processing methods through time limited our analysis. This analysis on economic, social and ecological resilience of Bayburt should be thought as a starter which should be supported with additional analysis that investigates the fragilities of the city.

\section{REFERENCES}

Abel ND, Cummıng HM, Anderies JM, 2006. Collapse and Reorganization in Socialecological Systems: Questions, Some Ideas, and Policy Implications. Ecology and Society, 11 (1): 17-42, http://www.ecologyandsociety.org/vol11/iss1/art17/. (Date of access: 15 April 2019).

Adger WN, 2000. Social and Ecological Resilience: Are They Related?. Progress in Human Geography, 24 (3): 347-364.

Aguirre BE, 2006. Preliminary Paper 356: On the Concept of Resilience. Disaster Research Centre, University of Delaware, Newark-USA. 
Baud ISA, Hordjick MA, 2009. Dealing With Risks in Urban Governance: What We Can Learn From Resilience Thinking. The 4th International Conference of the International Forum on Urbanism The New Urban Question - Urbanism beyond Neo-Liberalism, 26-28 November 2009, Delft.

Berkes F, Folke C, Berkes F, 1998. Linking Social and Ecological Systems: Management Practices and Social Mechanisms for Building Resilience. Cambridge University Press, Cambridge-UK.

Dursun D, Dursun D, Kaya AB, 2020. Urban Resilience Assessment of Trabzon. Iğdır Üniversitesi Fen Bilimleri Enstitüsü Dergisi / Iğdır Univ. J. Inst. Sci. \& Tech., 10 (2): 1286-1297.

Dursun D, 2018. The Concept of Resilience: A Critical Evaluation of Erzurum. Iğdır Üniversitesi Fen Bilimleri Enstitüsü Dergisi / Iğdır Univ. J. Inst. Sci. \& Tech., 8 (3): 295-304.

Dursun D, Dursun D, Yavas M, 2017. Resilience Planning and Urbanization Experience of Erzurum. International Conference on Spatial Planning and Sustainable Development, 19-20 August 2017, Seoula.

Dursun D, Yavaş M, 2016. Resilience Planning Approach and Urbanization Experience of Erzurum. 15. Regional Scince / Regional Planning Congress, 3-4 December 2015, Trabzon.

Dursun D, 2015. The Effects of Restructuring in the Property Development Sector on Urban Processes: A Case Study on Erzurum and Kayseri. METU The Program of Urban Policy Planning and Local Government, Doctor of Philosophy Thesis (Not Printed).

Eraydın A, 2010. Resilience Thinking for Urban Analysis And Planning: An Exploratory Research On Istanbul. 24th AESOP Annual Conference, 7-10 July 2010, Finland.

Eraydın A, Durmaz B, Erdem A, Yaman C, Yavuz B, 2011. The concept of Resilience: Ankara region case study. ODTÜ Bölge Planlama Yüksek Lisans Programı, Bölge Planlama Stüdyosu Çalışma Raporu (Not Printed).

Folke C, Carpenter S, Elmqvist T, Gunderson LH, 2002. Resilience and Sustainable Development: Building Adaptive Capacity in a World of Transformations. Edita Norstedts Tryckeri AB, Stockholm-Sweden.

Frantzeskaki N, 2016. Urban Resilience: A Concept for Co-Creating of the Future. Erasmus University, Rotterdam-Netherlands.

Gunderson L, Holling CS, 2001. Panarchy: Understanding Transformations in Human and Natural Systems. Island Press, Washington DC-USA.

Hill EW, Wial H, Wolman H, 2008. Exploring Regional Economic Resilience, Working Paper 2008-04. University of California, USA.

Maguire B, Hagan P, 2007. Disasters and Communities: Understanding Social Resilience. The Australian Journal of Emergency Management, 22(2): 16-20.

Resilience Alliance, 2007. Urban Resilience Research Prospectus. CSIRO, Australia Arizona State University, USA Stockholm University, Sweden.

TÜIKK, 2019a. Province Indicators

TÜİK, 2019b. Regional Statistics, GDP, www.tuik.gov.tr (Date of access: 20 April 2019).

TÜİK, 2019c. Regional Statistics-Population Census; ABPRS

TÜIK, 2019d. Regional Statistics, Education

TÜIK, 2019e. Regional Statistics, Migration

TÜIK, 2019f. Regional Statistics, Demography

Türkiye Bankalar Birliği, 2019. İstatistiki Raporlar, Bayburt, https://www.tbb.org.tr/tr/bankacilik/banka-vesektor-bilgileri/istatistiki-raporlar/59 (Date of access: 20 April 2019).

Walker B, Salt D, Reid W, 2006. Resilience Thinking: Sustaining Ecosystems and People in a Changing World. Island Press, USA. 